\title{
PROBLEMATIKA DAN MOTIVASI MENIKAHI WANITA MANAPOUSE DEMI KEUTUHAN RUMAH TANGGA MENURUT PERSEPSI MASYARAKAT KABUPATEN MUARA JAMBI
}

\author{
A.A.Miftah, Siti Marlina, Rahmi Hidayati \& Dian Mustika* \\ Universitas Islam Negeri (UIN) Sulthan Thaha Saifuddin Jambi \\ Email: miftah@uinjambi.ac.id
}

\begin{abstract}
Marriage is anyone's right as long as the marriage is in accordance with the Shari'a, women who are no longer menstruating are called menopause and in this phase women experience various changes, with this change the groom is expected to understand the problematics of marrying menopause women for the sake of continuing family integrity, to give an idea to a bride, especially a man who wants to marry a menopausal woman (who is no longer reproducible), this study aims to find out the problems and motivations of marrying a menopausal woman (not to be reproduced) and to know the review of Law No. 1 of 1974 and Islamic Law concerning marrying women manouse, this research is a qualitative research with an empirical normative sociological approach by using the interview method, with the technical writer asking the spouse directly as a respondent and from the results of the interview the writer is the data. The results of this study can be concluded First Problematics marrying menopausal women are: not getting offspring, changes in intimate partner relationships. and social impact in the community Second Motivation to marry menopausal women as follows: because they really want to get married, earn a living, undergo worship, have friends in old age and friends.
\end{abstract}

Keywords: Woman, Married, Manopouse

\begin{abstract}
Abstrak
Menikah adalah hak siapa pun asalkan pernikahan itu sesuai dengan syariat, wanita yang sudah tidak haid lagi dinamakan menopause dan pada fase ini wanita mengalami berbagai perubahan, dengan perubahan ini lah pengantin pria diharapkan dapat memahamai problematika menikahi wanita menopause demi keberlangsungan keutuhan keluarga, untuk memberi gambaran kepada seorang pengantin terkhusus seorang pria yang ingin menikahi wanita menopause (yang tidak repoduksi lagi), Penelitian ini bertujuan ingin mengetahui problematika dan motivasi menikahi wanita menopause (tidak repoduksi) serta ingin mengetahui tinjauan Undang-undang No 1 Tahun 1974 dan Hukum Islam tentang menikahi wanita manopouse, Penelitian ini merupakan penelitian kualitatif dengan pendekatkan sosiologis normative empiris dengan mengunakan metode wawancara,dengan teknis penulis menanyakan langsung kepada pasangan sebagai responden dan dari hasil wawancara tersebut penulis olah menjadi data. Hasil penelitian ini dapat disimpulkan Pertama Problematika menikahi wanita menopause adalah: tidak mendapatkan keturunan, perubahan pada hubungan intim pasangan. dan dampak sosial di masyarakat Kedua Motivasi
\end{abstract}

* Dosen Fakultas Syariah dan Hukum Universitas Islam Negeri (UIN) Sulthan Thaha Saifuddin Jambi 
ADHKI: Journal of Islamic Family Law

menikahi wanita menopause sebagai berikut: karena memang ingin menikah, mencari nafkah, menjalani ibadah, ada teman di masa tua dan teman.

Kata Kunci: Wanita, Menikah, Manopouse

\section{Pendahuluan}

Hukum keluarga biasa dikenal dengan sebutan al-ahwal assyakhsiyyah. Ahwal adalah jamak (prulal) dari kata tunggal (singular) al-halartinya hal,urusan atau keadaan. Sedangkan as-syakhsiyyah berasal dari kata as-syakhsu jamaknya asykhash atau syukhush yang berati orang atau manusia (al-insan). Assyakhshiyyah, berarti kepribadian atau identitas diri pribadi (jati diri) ${ }^{1}$

Defenisi tersebut memberikan rambu bahwa hukum keluarga mengatur hal, urusan atau keadaan setiap individu maupun kelompok masyarakat muslim dalam hal ini termasuk menikahi wanita menopause karena ini menyangkut keharmonisan keluarga. Di dalam KHI sendiri pada pasal 3 bab dasar-dasar perkawinan berbunyi "perkawinan bertujuan untuk mewujudkan keluarga sakinah,mawaddah, dan rahmah. ${ }^{2}$

Di indonesia hukum keluarga di atur di dalam Komplikasi Hukum Islam (KHI), ini yang menjadi pedoman umat muslim di indonesia dalam menjalankan syariat islam yang sudah berbaur dengan perkembangan hukum di indonesia,KHI sendiri berasal dari instrument fiqh,undang-undang perkawinan sendiri dicantumkan dalam bentuk UU No.1 tahun $1974^{3}$ dan pelaksanaan peraturan pemerintah UU No.9 tahun 1975. Setelah terjadi perkawinan dengan wanita menopause mampukah calon mempelai mencapai peringkat keluarga sakinah, wawaddah, dan rahmah itu sendiri tercapai karena wanita menopause mengalami penyebrangan defenisi dengan kententeraman keluarga, karena masa ini muncul masalah bagi wanita mulai dari gairah sex yang menurun, tidak puas dengan keadaan, pergeseran perubahan-perubahan fisik hingga dicap sebagai wanita tua tentu ini berpengaruh terhadap daya tarik wanita tersebut. Hal ini tentu akan berpengaruh pada kerharmonisan keluarga itu sendiri.

Permasalahan ini mungkin dianggap wajar bagi mereka yang memang telah menikah sejak masa haid masih normal, bagaimana jika ini terjadi pada lelaki yang baru menikah dengan wanita menopause tersebut bahkan lelaki tersebut masih perjaka tentu secara logis pernikahan semacam ini ingin mendapatkan kebutuhan biologis yang sempurna ini tidak didapat didalam tubuh wanita yang telah menopause secara gairah sex sudah terjadi nya penurunan, sebagian lelaki menikahi wanita menopause karena dengan status duda nya mereka ingin ada teman hidup dimasa tuanya atau bahkan yang lebih extrem nya lagi menikahi wanita menopause merupakan pilihan karena memang

${ }_{1}$ Muhammad Amin Suma, Hukum Keluarga Islam Di Dunia Islam, 2005 (Jakarta: Raja Grafindo Persada), Hlm. 17

${ }^{2}$ Komplikasi Hukum Islam Tentang Perkawinan Pasal 3 tahun 2001

${ }^{3}$ Undang-undang Perkawinan Indonesia Nomor 1 Tahun 1974 
sudah sangat cinta dengan wanita menopause dan baru bisa tercapai disaat moment yang tepat

- Menopause adalah suatu masa yang membuat wanita mengalami gangguan-gangguan fisik maupun psikis seperti depresi dan sebagainya. ${ }^{4}$ Sebagian wanita menopause mengalami gejala-gejala menopause yang cukup parah sehingga dapat mempengaruhi aktivitas mereka sehari-hari yang pada akhirnya dapat menurunkan kualitas hidup mereka. Sebagian besar wanita menopause tidak menyadari akan perubahan-perubahan yang mereka alami ketika memasuki masa menopause. ${ }^{5}$

Berdasarkan data wanita Indonesia yang memasuki masa menopause semakin meningkat tiap tahunnya. Sensus penduduk tahun 2000 jumlah perempuan berusia diatas 50 tahun baru mencapai 15,5 juta jiwa atau 7,6 \% dari total penduduk, sedangkan tahun 2020 jumlahnya diperkirakan meningkat menjadi 30,0 juta jiwa atau $11,5 \%$ dari total penduduk. ${ }^{6}$

Umumnya wanita yang telah memasuki fase menopause berada pada usia kisaran 50 tahun keatastentu menikahi wanita menopause itu sama dengan artinya menikahi wanita paruh baya,kalo saja diibaratkan sebuah batrai maka wanita yang telah memasuki fase menopause memiliki daya batrai yang lemah hal ini dikarenakan faktor-faktor yang berubah disaat fase menopause semisal gairah sex yang menurun,daya tarik yang berkurang dll. Dampak yang ditimbulkan bukan hanya dari segi hukum keluarga islam saja akan tetapi dampak yang timbul di sosial masyarakat seprti yang terjadi di Kabupaten Muara Jambi ada bebarapa pasangan pengantin menikahi dengan wanita yang sudah monapouse. ${ }^{7}$

Berdasarkan dari latar belakang diatas, bagaimana fenomena menikahi wanita menopause dapat menimbulkan dampak positif atau negatif dalam rumah tangga khususnya di desa penyengat olak,peneliti melakukan observasi terhitung ada beberapa pasangan yang melakukan pernikahan dengan status wanita nya telah memasuki fase menopause, peneliti menanyakan kepada wanita menopause banyak perubahan fisik maupun psikis pasca fase menopause itu datang bahkan merambat kepada dampak sosiologi sosial,hal ini yang membuat peneliti ingin mengetahui sejauh mana korelasi antara menikahi wanita menopause dan kehidupan rumah tangga pasangan tersebut, maka penulis tertarik untuk melakukan penelitian yang penulis tuangkan dalam penelitian ini.

4 Andira D. Seluk-Beluk kesehatan reproduksi Wanita. (Jogjakarta: A+ Plus Books; 2010), dikutip dari https://jurnal.unej.ac.id/index.php/JPK/article/download/816/628

${ }^{5}$ Rahman SASA, Zainudin SR, Mun VLK. Assesment of menopausal symptoms using modified menopause rating scale (MRS) among middle age women in Kuching, Sarawak, Malaysia [internet]. Asia Pacific Family Planning. 2010 [diakses 20 Desember 2012]; 9(5): 1-6. Available from: http://www.apfmj.com/content/pdf/1447 -056X-9-5.pdf

${ }^{6}$ Kementrian Kesehatan RI. 2005 dalam Milyandra 2010. Makalah Usia Harapan Hidup ${ }^{7}$ Hasil Observasi lapangan di Kabupaten Muara Jambi tahun 2019 


\section{Problematika Menikahi Wanita Menopause (Tidak Repoduksi) Terhadap Keutuhan Rumah Tangga}

Problematika itu sendiri jika diartikan secara sederhana adalah akibat sebuah tindakan yang dilakukan oleh seseorang atau kelompok dalam kasus ini pernikahan dilakukan antara pria dan wanita maka secara kuantitas bisa dikatakan berkelompok, pernikahan menopause sebenarnya tidak terlalu berbeda dengan pernikahan lazimnya hanya saja pada usia, tentu menopause adalah usia lanjut karena memang wanita menopause mengalami fase menopause terjadi pada usia kisaran 50 tahun keatas, dari sini secara naruli setelah menikah manusia akan melakukan hubungan suami istri usia lanjut membuat sebagian besar pasangan meninggalkan hubungan suami istri. Menopause, seperti halnya menarche dan kehamilan, dianggap sebagai peristiwa yang sangat berarti bagi kehidupan perempuan. Menarche pada remaja perempuan menunjukkan mulai diproduksinya hormon estrogen, sedangkan menopause terjadi ketika ovarium tidak lagi menghasilkan atau tidak memproduksi hormon estrogen. Pada usia 45 tahun, indung telur mengalami penuaan sehingga tidak lagi sanggup memenuhi hormon estrogen. Seluruh sistem hormonal akan mengalami kemunduran secara perlahan-lahan, dan perubahan pengeluaran hormon menyebabkan berbagai perubahan fisik dan berdampak pada kondisi psikis perempuan dalam menghadapi fase menopause, 8 dan secara alamiah akan berpengaruh terhadap hubungan seks suami istri.

Menurut Hawari, peristiwa menopause sama halnya seperti peristiwa menarche dan kehamilan yang dianggap sebagai peristiwa yang sangat berarti bagi kehidupan perempuan. Menopause adalah suatu fase dari kehidupan seksual perempuan, dimana siklus menstruasi berhenti. Bagi seorang perempuan, dengan berhentinya menstruasi ini berarti berhentinya fungsi-fungsi organ reproduksi, namun tidak berarti peranannya dalam melayani suami di bidang kebutuhan seksual berhenti dengan sendirinya. ${ }^{9}$ Pada masa menopause, tidak ada orang yang bisa lepas sama sekali dari rasa was-was dan cemas, termasuk para lansia menopause. Ketegangan perasaan atau stress selalu beredar dalam lingkungan pekerjaan, pergaulan sosial, kehidupan rumah tangga, dan bahkan menyelusup ke dalam tidur. Demikian juga dengan gejala depresi di masa menopause. Perempuan yang mengalami menopause sering merasa sedih, karena kehilangan kemampuan untuk bereproduksi, sedih karena kehilangan kesempatan untuk memiliki anak, sedih karena kehilangan daya tarik. Perempuan merasa tertekan karena kehilangan seluruh perannya sebagai perempuan dan harus menghadapi masa tuanya. ${ }^{10}$

\footnotetext{
${ }^{8}$ Manuaba, I.B.O. Memahami Kesehatan Reproduksi Perempuan. (Jakarta: Penerbit Arcan, 1999), hlm. 56

${ }^{9}$ Dikutip dari ejournal uin suska.ac.id/index.php/marwah/article/download/506/486 diakses 22 November 2019

${ }^{10}$ Ibid
} 
Ada beberapa faktor yang mempengaruhi gairah seksual wanita menopause menurun diantaranya adalah:

1. Perubahan pada vagina, hormon estrogen semakin berkurang hal tersebut yang berpengaruh pada vagina, akan tetapi ini bukanlah jalan buntu untuk tetap melakukan hubungan seksual dengan pasangan.

2. Perubahan cara pandang, tentu menopause ini erat kaitannya dengan usia lanjut maka perubahan seperti tubuh tak seindah dulu, kecantikan berkurang, bagi pasangan modal percaya diri akan berpengaruh pada performa pasangan itu sendiri.

Berdasarkan hasil wawancara dengan Bapak HRN seorang pasangan menikahi wanita monopouse mengatakan sebagai berikut:

"Karena memang saya sebelum menikah yang sekarang, saya sudah menikah terlebih dahulu pada sebelumnya dan tidak dikaruniakan anak perempuan, kalo anak laki-laki kita tahu kalo di jambi ini dia keluar rumah dan saya sekarang sudah tua maka dari itu siapa lagi yang merawat saya, untuk masalah tidak mendapatkan anak menikahi menopause ini saya serahkan kepada Allah SWT"11

Dengan demikian pernikahan dengan wanita menopause memiliki dampak sebagai berikut :

1. Tidak Mendapatkan Keturunan

Anak merupakan amanah dari tuhan untuk kita rawat dan kita didik agar menjadi anak sholeh dan sholehah, kehadiran sibuah hati di tengah-tengah keluarga menjadi perasaan penuh bahagia,ini ketika menikah pada masa sebelum menopause dikategorikan aman dan tidak menjadi masalah karena secara normatif wanita dapat melahirkan pada usia dibawah usia fase menopause. Seksualitas dapat mempengaruhi kualitas hidup perempuan dan memiliki dimensi biologis, sosial, etik, dan budaya. Satu yang penting dari bahasan kualitas hidup para perempuan adalah masalah seksualitas. Seksualitas merupakan aspek penting untuk mengukur status kesejahteraan seorang individu yang secara bermakna dapat terganggu karena suatu penyakit dan terapinya. ${ }^{12}$

2. Perubahan pada Hubungan Intim Pasangan

Seperti yang dibahas sebelumnya, menopause mengakibatkan produktifitas wanita berkurang, kondisi ini berbeda dengan kaum lelaki di mana pada mereka terjadi penurunan fungsi hormonal pada testis sedikit demi sedikit bersamaan dengan semakin bertambahnya usia, hal ini disertai dengan tandatanda perubahan seperti yang ada pada wanita, adapun kemampuan lelaki dalam memproduksi cairan mani tidak akan berkurang sama sekali ${ }^{13}$

\footnotetext{
${ }^{11}$ Wawancara dengan Bapak HRN, 1 juni 2019

${ }^{12}$ Yati Afiyanti dan Anggi Pratiwi Seksualitas Dan Kesehatan Reproduksi Perempuan (Depok:Rajagrafindo,2016). hlm 10

${ }^{13}$ Majdi Muhammad Asy-syahawi dan Aziz Ahmad Al-Aththar Kado Pengantin (solo : Pustaka Arafah, 2006). Hlm 358-359
} 


\section{Dampak Sosial di Masyarakat}

Dalam hidup bersosial kita menjalani hidup ini tentu tidak selalu positif dan menyenangkan, terkadang apa yang kita perbuat belum tentu orang lain senang ada saja cemoohan, ejekan, penilaian masyarakat terhadap wanita menopause ini dipandang wanita tua yang tak perlu lagi untuk menikah, akan tetapi fokus di masa tua dengan beribadah guna bekal di akhirat kelak, wanita menopause rata-rata tersemat status janda, hal ini juga yang menjadi varian masyarakat dalam mencibir pasangan menopause, dengan mengatakan ada motif tersendiri dalam menikahi wanita menopause yang sekaligus wanita janda tersebut dampak sosial dari memikahi wanita menopause adalah anggapan remeh dari lingkungan sekitar bahwasanya pernikahan akan sukses, dalam artian berumah tangganya akan adem ayem, serta ucapan usia tidak perlu lagi menikah. Sebagaimana hasil wawancara peneliti dengan Ibu JMN salah seorang Janda:

"Orang disekitar rumah,ada satu dua yang memberikan komentar negatif,mereka bilang untuk apa menikah lagi sudah tua,mereka tidak menyakini kesetiaan pasangan saya,dan saya tidak perduli apa kata orang-orang yang penting saya menjalani nya dengan baik"14

Dari hasil wawancara diatas dapat ditarik penjelasan bahwa, menikah wanita menopause tidak terlepas dari cibiran orang-orang, dikarenakan ada yang meremehkan kesetiaan, serta urgensi untuk menikah lagi, responden tidak memperdulikan apa kata orang, dan rata-rata responden yang peneliti tanyakan sudah pernah menikah sebelumnya, ini juga selain faktor menikahi wanita menopause, faktor dikarenakan sudah pernah menikah sebelumnya juga sebagai alasan responden mendapat komentar miring.

4. Psikologis Pasangan

Tantangan rumah tangga wanita menopause dan pasangannya akan jauh berbeda dengan pasangan yang menikah di usia ideal, wanita menopause mengalami perubahan fisik, tingkat kesuburan dan kualitas sperma nya sudah berkurang hal ini berdampak pada ketidak nymanan dalam menjalani kehidupannya, bertambahnya usia tua sudah menjadi takdir nya manusia tidak bisa dihindari lagi, konsekuensi wanita menopause dari segi psikologis mulai dari ingatan menurun, kecemasan, mudah sakit-sakitan. Dan ini menjadi tantangan individual masing-masing wanita menopause dalam menjalani gejala psikologis tersebut, jika dikaitkan dengan pernikahan wanita menopause dan pasangannya, maka hal dalam ini pasangan memerlukan komitmen untuk saling menerima keadaan setiap pasangan, tentu psikologis menikah diusia ideal dan menikah pada fase menopause berbeda.

\section{Motivasi Menikahi Wanita Menopause Demi Keutuhan Rumah Tangga}

${ }^{14}$ Wawancara dengan Ibu JMN tanggal 1 juni 2019 
Manusia dalam proses perkembangannya untuk meneruskan jenisnya membutuhkan pasangan hidup yang dapat memberikan keturunan sesuai dengan apa yang diinginkannya, perkawinan sebagai jalan untuk bisa mewujudkan suatu keluarga/rumah tangga yang bahagia dan kekal berdasarkan ketuhanan yang maha esa, islam tidak mengatur batas kemampuan menikah itu dilihat dari segi kematangan lahiriyah dan batiniyah, ketika membuat keputusan ingin menikah wanita menopause, maka keputusan tersebut dibarengi dengan dorongan untuk melangsungkan pernikahan, dorongan atau motivasi untuk menikah itu sendiri bukan hanya datang dari pihak lelaki, dorongan itu datang juga dari pihak perempuan, mulai dari ingin ada teman di usia tua, teman berkomunikasi hingga memang ingin menikah atau bahkan memiliki background yang sama pada perjalanan nya memilih menikah pada usia tua karena memang menopause berada pada posisi umur menginjak 50 tahun keatas maka dikategorikan tua, ada hal yang dijumpai seperti ketika wanita menopause tersebut memiliki anak dan anaknya tersebut tidak menyetujui pernikahan yang dilakukan orang tua nya, dan juga cibiran dari orang-orang yang meragukan keputusan untuk menikah lagi, apapun itu dorongan untuk menikah dengan wanita menopause harus sejalan dengan syariat islam dengan kata lain tidak melanggar fiqih munakahat (pernikahan).

Menurut Islam, reaksi adekuat dimanifestasikan dari tindakan memandang menopause sebagai hal yang alamiah/sunnatullah bahkan disyukuri atas kenikmatan yang diberikan Allah, maka individu akan menghadapinya dengan penuh penerimaan dan keikhlasan sehingga berbagai gangguan fisiologis yang dialaminya tidak berdampak pada gangguan psikologis. ${ }^{15}$

Menopause terjadi pada masa klimakterium, yang mana terjadi peralihan dari fase reproduktif ke fase non-reproduktif. ${ }^{16}$ Perubahan ini biasa terjadi dua sampai lima tahun, dan pada umumnya terjadi pada perempuan antara umur 45 sampai 55 tahun. Pada masa perubahan tersebut dapat juga disebut sebagai climacteric atau sering disebut dengan perubahan dalam hidup (masa transisi).

Menurut Retnowati menyebutkan. Di usia menopouse, biasanya perempuan mempunyai putra-putri yang sudah besar dan dewasa, yang perlahan-lahan mulai memiliki kehidupan sendiri. Ketergantungan mereka terhadap orang tua mulai berkurang sehingga fungsi dan peran orang tua pun tidak sebesar dulu lagi. Bagi perempuan yang terbiasa terlibat secara intens dalam kehidupan anaknya, hal ini merupakan keadaan yang sulit untuk diterima. Disadari atau tidak, pelan-pelan mulai timbul perasaan diabaikan, tidak diperhatikan, tidak berguna/tidak berperan lagi yang kemudian mengarah

${ }^{15}$ Retnowati, S., Tetap Bergairah Memasuki Usia Menopause: Sebuah Tinjauan Psikologis. Disampaikan pada Seminar Ilmiah Populer dalam Rangka Milad ke 78 RSU PKU Muhammadiyah Yogayakarta, 2001 di akses 22 November 2019.

${ }^{16}$ Halim, S.. Memelihara Kesehatan Reproduksi. (Jakarta: Obor, 1996), hlm, 97 
ke rasa kesepian. ${ }^{17}$ Sebelum menikahi wanita menopause diperlukan juga keputusan yang matang untuk dijadikan pendamping hidup, memahami latar belakang pasangan agar pernikahan tersebut dapat terwujud, berbicara mengenai masalah menopause akan menimbulkan berbagai tanggapan dan penilaian yang berbeda pada masing-masing individu pengetahuan mengenai menopause itu sendiri, meski usia tak muda lagi, yang nama nya lansia tetap saja memiliki perasaan, merasakan sepi dan ingin berbagi dengan seseorang yang cocok dengan mereka hanya saja jenisny sedikit berbeda, cinta lansia tidak mengebu-gebu seperti halnya orang-orang muda niatan manula menikah biasanya atas dasar pertimbangan.

Ada motivasi tersendiri untuk menikah dengan wanita menopause itu sendiri, berikut adalah motivasi menikahi wanita menopause:

1. Karena Memang Ingin Menikah.

Perkawianan merupakan implementasi naruli dari setiap manusia,dan islam sendiri memberikan pedoman untuk memilih pasangan, terkadangcinta tak mengenal tempat,baik itu muda maupun tua,ketika saling berpandangan maka disitulah hadirnya cinta, kalau dari segi kesiapan mental usia menopause sudah tidak diragukan lagi kematangannya karena sudah banyak makan garam kehidupan,meskipun usia tua akan tetapi perlu juga adanya pengesahan hubungan antara suami dan istri. Pertemuaan seorang lelaki dengan seorang wanita atas dasar nama Allah untuk membentuk keluarga memerlukan ramburambu yang bisa melindungi akhlak dan agama. Di sana ada pula pertimbanganpertimbangan lain berkenaan dengan kecantikan, harta, ataupun kedudukan, dan bertautan pada status pihak wanita : gadis ataukah janda, dan status pria: perjaka, duda, ataupun pernah bercerai.

Pertimbangan-pertimbangan ini kembali kepada kecenderungan dan pilihan masing-masing individu, serta pilihan mana yang bisa mewujudkan kebahagian bagi kedua belah pihak, seorang wanita tak bisa ditolak keinginannya untuk menikah hanya karena ia janda ataupun pernah bercerai. Demikian pula seorang pria tak bisa ditolak keinginannya untuk menikah hanya karena ia duda ataupun pernah bercerai. Persoalan ini memerlukan pertimbangan matang, pemikiran masak, diskusi, dan konsultasi. ${ }^{18}$

Keinginan menikah pada saat menopause ini berdasarkan hasil wawancara dengan responden :

"Iya nama nya manusia ini kan ada naruli lah untuk saling mencintai, saya dan suami ini dijodohkan, ketika itu ketemu nya di sei.bahar, iya kita bertemu dan tidak menunggu waktu lama, sudah cocok ya langsung saja meskipun tua kita pake acara selamat juga lah biarpun kecil-kecilan lah kan"19

17 Dikutip dari ejournal uin suska.ac.id/index.php/marwah/article/download/506/ 486 diakses 22 November 2019

${ }^{18}$ M. Sayyid Ahmad Al-Musayyar fiqih cinta kasih (jakarta:erlangga,2008)hlm118-119

${ }^{19}$ Wawancara dengan Ibu NJH, tanggal 28 januari 2019. 
Kebahagian dalam merajut kasih dan sayang adalah milik siapa saja, pernikahan itu normal dan tentu harus mengikuti syariat yang telah ditentukan, karena memang pada dasarnya manusia diciptakan hidup berpasang-pasangan.

2. Mencari Nafkah

Nafkah disini ialah suami memberikan nafkah kepada istrinya, karena suami bertanggung jawab terhadap istrinya dari segi materi dan istri bertanggung jawab terhadap suaminya dari segi perasaan. ${ }^{20}$

Berangkat dari pengertian nafkah tersebut, fungsional lelaki memang mencari nafkah, perempuan bisa saja mencari nafkah tetapi itu hanya sebagai penopang saja, ketika belum menikah maka untuk memenuhi kebutuhan responden hanya mengharapkan dari pemberian oleh sang anak, dan setelah terjadi nya pernikahan maka untuk memuhi kebutuhan terbantu dengan hadirnya suami dalam mencari nafkah, seperti yang diutarakan oleh Ibu ERN sebagai berikut ini:

"Dengan keadaan seperti ini, ekonomi lemah, bisa saja anak yang memberi terus kepada saya,tetapi itu tadi ekonomi anak saya pun juga lemah, dengan saya menikah suami saya akan membantu dalam hal memenuhi kebutuhan hidup'21

Dengan dilatar belakangi ekonomi berkecukupan maka jalan menikah adalah salah satu jalan untuk memenuhi kebutuhan, meskipun masa tua tak sama dengan masa muda, fisik yang mulai menurun, tetapi untuk kebutuhan harus tetap terpenuhi, dan nafkah suami kepada istri adalah wajib.

3. Menjalani Ibadah dengan Baik

Sejatinya para lansia juga memiliki hukum sama seperti mereka yang masih muda, bagi seorang muslim, memandang lawan jenis dengan hasrat juga bisa dikatakan maksiat, maka rasul sendiri senantiasa mengingatkan para umatnya untuk selalu menjaga pandangan tak peduli usia muda ataupun tua, dari sana bisa disimpulkan bahwa yang disunnahkan menikah bukanlah bagi mereka para muda-mudi yang lajang saja mereka para duda janda lansia kategori menopause dengan menikah untuk menjaga kejernihan hati dan jiwa menjaga usia senja mereka agar terhindar dari penumpukan dosa karena pandangan yang tak sepantasnya. Tentu hal ini berlaku bagi pasangan muda maupun tua, hal ini pula lah yang menjadi dorongan pernikahan dengan wanita menopause.

Wanita pada masa haid normal ada waktu yang ditentukan untuk tidak beribadah, karena wanita akan melalui siklus haid dan ketika menopause wanita tidak memikirkan lagi hal tersebut, karena menopause sudah tidak berlaku akan hal itu karena memang wanita menopause sudah 'kering' sesuai dengan pernyataan responden sebagai berikut ini:

${ }^{20}$ Syaikh Muhammad ash-Shayim, Tips Menjaga Cinta Suami (Jakarta:Najla press,2005).

${ }^{21}$ Wawancara dengan Ibu ERN, tanggal 1 juni 2019. 
"Kalau lah tua ini (keadaan menopause) kalau mau beribadah itu enak soal nya apa? iya kita tidak memikirkan atau khawatir lagi tamu kita datang (datang bulan)'22

Pernyataan responden tersebut mengisyaratkan bahwa bagaimana keadaan ketika menginjak fase menopause dalam menjalankan ibadah lebih tenang dan nyaman selaras dengan masa tua yang boleh dikatakan adalah masa persiapan untuk akhirat kelak, dengan menjalankan ibadah dengan suami yang menjalankan tugas sebagai imam dalam rumah tangga membuat ibadah semakin nikmat dijalani.

4. Ada Teman dimasa Tua

Menemani pasangan sampai akhir hayat bukan saja milik yang muda saja, usia lanjut juga membutuhkan seorang teman agar terhindar dari waktuwaktu jenuh nya, rumah kecil pun kalo sendiri saja dirumah itu terasa besar dan luas karena kesepian yang melanda dan bisa saja berpotensi menjadi depresi, dengan adanya pasangan yang menemani bisa saling mengisi satu sama lain, usia tua ini merupakan fase yang sudah tidak lagi mencari jati dirinya, tetapi sudah di fase tenang bisa saja anak dan cucu menemani, memang sebagian orang sudah merasa cukup dengan ditemani anak dan cucu,akan tetapi ada juga yang butuh pendamping, saling melengkapi, ketika lelah ada istri yang mengambil minum, sesederhana itu tapi sangat berati bagi pasangan hal ini sesuai dengan penuturan responden sebagai berikut:

"Kalau sudah tua ini kan badan sudah tidak kuat seperti muda lagi kan, kalau ada pasangan ini kan bisa saling melengkapi lah, sholat bersama, ngaji bersama kalau sudah tua kan, ngumpuli amal untuk menghadapi akhirat kelak, kalau untuk ke umo (sawah) masih telap lah, iya tapi tidak sekuat dulu lagi, balik lagi tadi kan, iya memang nikah meskipun pasangan sudah menopause di rumah ada yang menemani, bangun tiduk ada yang ditengok, kita dak mau kalah sama anak muda, kalau masak sama-sama lah, masih ada romantis biarlah tua kan inti nya masa tua tidak sepi lah"23

Dari penuturan responden, sebagai makhluk sosial manusia memerlukan bantuan orang lain, memerlukan bantuan disini, dengan melaksanakan pernikahan dengan demikian suami akan dapat membimbing istri semangat menjalankan norma-norma agama hukum islam, tidak menentuan kapan usia yang baik atau yang ideal untuk melangsungkan perkawinan, meskipun harus memperhatikan kesehatan suami istri, kebahagian milik siapa saja, termasuk kebahagian di hari tua.

5. Teman Berkomunikasi

Ketika ada problem atau uneg-uneg ada keinginan teman komunikasi yang selalu ada dengan menikahi wanita menopause ini permasalahan itu pun

${ }^{22}$ Wawancara dengan Ibu JMH tanggal 1 juni 2019

${ }^{23}$ Wawancara dengan Bapak HRN tanggal 1 juni 2019 
terjawab, moment kebersamaan diciptakan dengan terciptanya komunikasi yang baik, bahkan akibat dari perceraian adalah komunikasi yang kurang antara suami dan istri, memahami satu sama lain adalah salah satu kunci kesuksesan hubungan rumah tangga, menjadi suatu hal wajar jika pasangan menopause ingin ada teman komunikasi,lalu bagaimana komunikasi pasangan menopause seperti kata Bapak EDY sebagai berikut:

"Iya capek badan ada teman ngobrol,suntuk juga kalau diam-diam aja, ada lah tv tidak mempan, ngobrol sama to tidak mungkinlah, semenjak menikah teman komunikasi jadi ada tempat curhat nya, nanya seputar agama diskusi soal agama, macam-macam lah pembahasan lah kan, sebelum tidur ada teman ngobrol jadi tidak sepi lagi" 24

Dari peryataan responden tersebut, komunikasi inti nya menjadi obat agar terhindar dari kesepian, apa saja bisa jadi bahan obrolan, kekuatan komunikasi ini menjadi pererat hubungan menciptakan ruang kebersamaan diantara pasangan, pasangan menopause menikah untuk mencari teman komunikasi tentu ini menjadi tujuan pasangan lain artinya pasangan yang tidak berada pada fase menopause pun ingin menikah sebagai ikhtiar mencari teman komunikasi sepanjang hidup tapi kembali lagi, pernikahan menopause merupakan status wanita dari segi emosional sudah tenang dan gudang perjalanan hidup sudah banyak.

Di dalam kehidupan bermasyarakat, tokoh masyarakat dipandang sebagai "orang yang dituakan" berbagai macam permasalahan yang dianggap perlu pandangan tokoh masyarakat dalam melihat permasalahan tersebut maka permasalahan tersebut dibawa ke tokoh masyarakat sebagai tempat bertanya dan juga meminta nasehat

Kantor Urusan Agama (KUA) adalah bagian dari depertemen agama yang membidangi agama di tingkat kecamatan dalam pembinaan dan pelayanan munakahat, perwakafan, zakat, ibadah sosial, penyuluhan dan lain-lain di dalam menjalankan fungsi dan tugas nya kantor urusan agama dipimpin oleh kepala kantor yang disebut juga sebagai kepala KUA, lalu bagaimana pendapat tokoh masyarakat melihat dampak menikah wanita menopause ini, berikut pendapat tokoh masyarakat Kabupaten Muara Jambi dan kepala KUA Kecamatan Jambi Luar Kota mengenai permasalahan tersebut.

1. Tokoh Masyarakat

Di Kabupaten Muara Jambi pernikahan dengan menopause dilakukan secara sirih, dan adat yang dipakai tetap sama akan tetapi yang membedakan hanya separuh saja, istilah menopause ditelinga masyarakat masih terdengar asing, harus dijelaskan apa itu menopause baru masyarakat faham hal ini dikarenakan faktor pendidikan, pernikahan menopause ini memang banyak didapati di daerah perdesaan dan panti jompo meskipun susah-susah gampang

${ }^{24}$ Wawancara dengan Bapak EDY tanggal 28 Januari 2019 
dalam mencari nya, dalam sosial masyarakat ini pernikahan menopause bisa diterima masyarakat akan tetapi ada juga masyarakat yang tidak menerima dalam bentuk cibiran,dan sikap meremehkan hal ini tak lain karena faktor usia menopause itu sendiri.

Pernikahan menopause ini merupakan pilihan bagi mereka artinya pernikahan ini dilakukan oleh orang yang memang ingin menikah, di dalam islam sendiri tidak ada larangan yang membatasi maksimal usia pernikahan tentu yang membedakan ialah kualitas pernikahan itu sendiri, diera keterbukaan digital seperti sekarang ini orang di belahan dunia mana saja masih bisa berkomunikasi dengan bantuan smart phone, melek teknologi tidak saja melanda anak muda orang tua pun terjangkit melek teknologi tersebut.

Dalam kategori usia pasangan menopause dalam mengalami berbagai situasi hidup hal ini yang membuat tokoh masyarakat atau pun tokoh agama dinilai tidak perlu lagi memberikan nasihat kepada pasangan menopause dengan alasan tadi, berbeda dengan pasangan yang menikah pada usia muda sudah sering kita jumpai ketika ijab kabul selesai,maka tokoh agama,penghulu ataupun orang yang ditunjuk pihak keluarga memberikan nasehat perkawinan kepada pasangan hal ini sudah menjadi bagian rutinitas di Kabupaten Muara Jambi.

Sebagaimana pendapat tokoh masyarakat mengenai pernikahan menopause ini, peneliti menanyakan kepada bapak Ilyas A. Somad tokoh masyarakat yang juga sekaligus menjabat ketua BPD Kabupaten Muara Jambi dari hasil wawancara berikut:

"Memang ada pernikahan seperti itu, iya itu normal saja dan tidak melangar adat kalau pasangan itu mampu iya silahkan saja, tapi kebanyakan pernikahan dilakukan secara sirih kendati demikian adat tetap hanya saja dibayar separuh,pesan saya kepada pasangan tidak ada iya karena memang secara usia sudah sangat dewasa lah kalo berfikir dan sejauh ini untuk efek ke desa tidak ada lain kalau efek ke pasangan, tidak tau ada atau tidak karena itu memang wilayah individu nya pasangan'"25

Dari penjelasan tokoh masyarakat tadi pernikahan menopause bolehboleh saja dengan anggapan itu hal yang normal,tetapi kalo adat untuk pernikahan tetap dibayar dengan catatan dibayar separuh saja,tokoh masyarakat mengisyaratkan bahwa pernikahan menopause boleh dilakukan selagi memang itu menjadi kehendak pasangan dan mampu untuk melakukan nya.

2. Kepala Urusan Agama Kecamatan Jambi Luar Kota

Data pernikahan menopause yang terkodifikasi di Kantor Urusan Agama (KUA) Kecamatan Jambi Luar Kota bisa dibilang 1 banding 10, hal ini senada dengan apa yang disampaikan oleh tokoh masyarakat bahwa kebanyakan pernikahan menopause ini dilakukan secara sirih,pilihan pasanagan untuk nikah

${ }^{25}$ Wawancara dengan bapak Ilyas A.Somad, tokoh masyarakat tanggal 1 juni 2019 
secara sirih dikarenakan faktor kepentingan buku nikah tersebut sudah habis fungsi, adapun semisal adanya permasalahan mengenai warisan maka penyelesain nya dilakukan secara adat, ini menunjukan bahwa bukuh nikah tidak diperlukan lagi, seperti diketahui nikah sirih sah menurut agama jika memenuhi rukun dan syarat nikah akan tetapi menurut administratif negara tidak sah, karena pasangan mengangap bahwa urusan administratif dengan buku nikah sudah dianggap tidak perlu, ini lah salah satu alasan mengapa pernikahan menopause dilakukan secara sirih.

Sebagaimana pendapat kepala Kantor Urusan Agama terhadap pernikahan menopause ini:

"Pada dasarnya laki-laki itu pengen dilayani,maka menikah menjadi jalan untuk mendapatkan pelayanan itu,pelayanan itu bermakna dengan contoh istri masakin suami,atau istri sekedar memijit suami, dan dari segi hubungan suami istri(sex) laki-laki ini masih mampu lah kalau perempuan iya istilah nya itu sudah kering lah, tetapi kan macam-macam juga orang pengen nikah di fase menopause tersebut dan menurut saya itu boleh saja asal memang memenuhi rukun dan syarat nikah"26

Dari hasil wawancara tersebut menurut pandangan Kepala Kantor Urusan Agama Kecamatan Jambi Luar Kota pernikahan dengan wanita menopause sah-sah saja, selagi itu memang memenuhi rukun dan syarat nikah, berbeda dengan para kaum wanita lansia yang bisa berdiri sendiri tanpa hasrat berhubungan intim, para lelaki memiliki nafsu seperti perjaka, meski usianya sudah lanjut, meski usia sudah menua mereka masih mudah terangsang dan bersinggungan dengan hal-hal yang membngkitkan nafsu, mungkin sudah sering kita mendengar berita tentang kasus kakek-kakek yang melakukan hal cabul terhadap cucu atau kerabatnya, hal tersebut tentu imbas dari rasa sepi dan juga masih sangat mereka buntuhkan, dari pada hal mengerikan tersebut sampai terjadi alangkah lebih baik jika para lelaki lansia menikah, hal tersebut diharapkan akan membahagiakan dan menghindarkan dari hal-hal negatif seperti kasus cabul dan sebagaiannya.

Memang didapati juga bahwa tidak mau lagi nikah karena sudah cukup dengan cucu dan anak saja dan ada tidak mau lagi nikah dikarenakan tidak di perbolehkan oleh anak untuk nikah lagi, beragam faktor yang menjadi alasan untuk menikah lagi atau tidak di fase menopause tersebut.

\section{Kesimpulan}

Adapun dari hasil penelitian diatas bahwasannya dampak menikahi wanita menopause adalah: Pertama Tidak Mendapatkan Keturunan Seksualitas yang terjadi pada fase menopause mempengaruhi wanita dalam mendapatkan

${ }^{26}$ Wawancara dengan Bapak Drs. Zainal Arasy kepala kantor urusan agama tanggal 21 juli 
keturunan, karena wanita mengalami perubahan secara signifikan, hal ini yang membuat wanita sulit untuk mendapat keturunan. Kedua Perubahan pada Hubungan Intim Pasangan Sebagai pasangan suami dan istri kebutuhan biologis menjadi aktifitas yang lumrah dilakukan pasangan, lelaki yang sudah tua sekalipun masih tetap bergairah dalam masalah sexualitas berbanding terbalik dengan wanita menopause ataupun lansia sudah mengalami penurunan sexualitas. Ketiga Dampak Sosial di Masyarakat Sebagaian masyarkat menilai menikahi wanita menopause diragukan kesetian dan usia tua tak perlu lagi menikah, fokus pada ibadah sebagai bekal di akhirat kelak.

Sedangkan motivasi menikahi wanita menopause sebagai berikut: Pertama Karena Memang Ingin Menikah Cinta tak mengenal tempat, baik itu muda ataupun tua, ketika saling berpandangan maka disitulah hadirnya cinta, melakukan pernikahan adalah hal normal termasuk menikah dengan wanita menopause. Kedua Mencari Nafkah, dalam rumah tangga tugas dan fungsi suami istri dibagi-bagi, dalam hal urusan rumah tangga maka itu menjadi tanggung jawab istri dan mencari nafkah adalah tugas suami dengan menikah maka kombinikasi ini menjadi hal yang baik. Ketiga, Menjalani Ibadah dengan Baik Hukum tidak mengenal status, bagi seorang muslim memandang lawan jenis termasuk maksiat, menikah menjakan ibadah dengan baik, apalagi wanita menopause tidak terhalang oleh haid dalam menjalankan ibadah, dan masa tua dianggap sebagai persiapan di akhirat kelak. Keempat, Ada Teman di Masa Tua, Menemani pasangan sampai akhir hayat bukan saja milik yang muda saja,usia lanjut juga membutuhkan seorang teman agar terhindar dari kejenuhan. Kelima, Teman Berkomunikasi .Dengan menikah maka komunikasi dua arah dapat dilakukan hal ini dikarenakan karena sudah menjadi suami dan istri,komunikasi dapat mengobati kejenuhan dan tempat saling bertukar pikiran.

\section{Daftar Pustaka}

\section{Buku}

Abu Zahwa Dan Ahmad Haikal Buku Pintar Keluarga Sakinah,Jakarta Qultum Media

Amir Syarifuddin Hukum Perkawinan Islam Di Indonesia,Jakarta:Kencana Prenada Media Group 2009

ejournal.uin-

suska.ac.id/index.php/marwah/article/download/506/486akses22desembe r 2017

Halim, S.. Memelihara Kesehatan Reproduksi. (Jakarta: Obor, 1996)

https://jurnal.unej.ac.id/index.php/JPK/article/download/816/628 akses desember 2017

Husaini Usman Dan Purnomo Setiady Akbar Metodologi Penelitian Sosial,Jakarta:Bumi Aksara, 2008

Komplikasi Hukum Islam Tentang Pernikahan tahun 2001

M.Quraish Shihab Tafsir Al-Misbah,Jakarta:Perpustakaan Nasional, 2009 
M.Sayyid Ahmad Al-Musayyar fiqh cinta kasih,Jakarta,:Erlangga,2008

Mahmud Yunus, kamus Arab-Indonesia, (Jakarta:Hidakarya Agung, 1989)

Majdi Muhammad dan Aziz Ahmad Al-Aththar kado pengantin,solo:Pustaka Arafah,2006

Muhammad Amin Suma, Hukum Keluarga Islam Di Dunia Islam Jakarta : Rajagrafindo Persada, 2008

Peter Salim Dan Yenny Salim Kamus Bahasa Indonesia Kontemporer,Jakarta:Modern English Press, 1995

Retnowati, S., Tetap Bergairah Memasuki Usia Menopause: Sebuah Tinjauan Psikologis.Disampaikan pada Seminar Ilmiah Populer dalam Rangka Milad ke 78 RSU PKU Muhammadiyah Yogayakarta, 2001

Sayuti Una,Pedoman Penulisan Skripsi,(Edisi Revisi), Jambi:Syariah Press,2014

Su'ad Ibrahim Shalih Fiqih Ibadah Wanita,Jakarta:Amzah, 2013

Syaikh Hasan Ayyub Fikih Keluarga,Jakarta:Pustaka Al-Kautsar, 2003

Syaikh Imad Zaki Al-Barudi Tafsir Wanita, Jakarta: Pustaka Al-Kautsar 2004

Syaikh Muhammad,tips menjaga cinta suami, Najla press:Jakarta,2005

Tina Nk Dan Dwia Aries Menopause Dan Seksualitas, Yogyakarta: Perpustakaan Nasional, 1999

Undang-undang Perkawinan No 1 Tahun 1974

Yati Afiyanti,Skp,MN dan Anggi Pratiwi,Skep seksualitas dan kesehatan reproduksi perempuan,jakarta :Raja Grafindo,2016

Yayasan Bina Pustaka Sarwono Prawirohardjo Menopause Dan Andropause,Jakarta,2003 